\title{
Ciência de Dados e Ciência da Informação
}

Desde 0 início do século XXI temos ouvido falar em Big Data, que representa o grande volume de dados que estamos produzindo e acumulando desde que os computadores se tornaram os companheiros imprescindíveis dos humanos no planeta Terra. São dados relativos às inúmeras ações que desenvolvemos no nosso cotidiano, mas neste espaço nos interessa mais de perto aqueles referentes à produção científica. E aqui chegamos à Ciência dos Dados.

"[...] A cada 10 minutos, o volume de dados gerados no mundo todo é maior do que o volume de dados gerados desde a pré-história até 0 ano de 2003. Junto com esse aumento na geração de dados também aumentou a nossa capacidade de processamento. [...] a ciência de dados faz uso da análise preditiva e tenta descobrir "o que vai, ou pode acontecer." (WIKI, 2019)

Essa área, que alguns pesquisadores começam a apontar como nova fronteira de estudos no campo da informação, se interessa pelo que está acontecendo e mesmo pelo que já aconteceu - e aqui encontramos um link entre a Ciência de Dados e a comunicação científica, objeto de interesse do campo de estudos da Ciência da Informação. E, também, com a proposta de uma Ciência Aberta, onde não somente os resultados das pesquisas são compartilhados como, também, os dados coletados ou produzidos no decorrer do trabalho científico, de modo que outros pesquisadores possam utilizá-los em processos similares. Ganhamos credibilidade quando compartilhamos, e também ganhamos tempo - muitas vezes precioso - quando podemos retomar rotas e caminhos já percorridos, com ganhos inestimáveis nesse processo.

Esse processo de crescimento e consolidação da Ciência de Dados também pode ser observado no campo da Ciência da Informação. Uma busca na Brapci, usando o termo <ciência de dados> no período 1972 a 2019, recuperou 331 arquivos, iniciando a série histórica em 1977, inclusive um de Tefko Saracevic, publicado na revista Ciência da Informação em 1979, sobre o progresso da Ciência da Informação e sua contribuição para a criação de novos serviços profissionais nas escolas de Biblioteconomia.

E é sobre essa perspectiva que falam, no tempo presente, Semeler e Pinto (2019, p.113 a 166 passim), na mesma revista Ciência da Informação, quando dizem que

"[...] a ciência com uso intensivo de dados institui nova dimensão para os bibliotecários, a biblioteconomia de dados. [...] No entanto, o que são dados? [...] dados serão considerados como todo objeto criado em formato digital (digital-born) ou convertido para o formato digital (digitalizados) que possa ser usado para geração de insights de informação e conhecimento. 
[...] o bibliotecário de dados deve possuir as habilidades necessárias para trabalhar com qualquer tipo de dados, sejam eles observacionais, computacionais ou experimentais."

Mostrando-se antenados com o tempo em que vivemos, pesquisadores do Programa de PósGraduação em Ciência da Informação da Universidade Federal da Paraíba organizaram o livro Dados científicos > Perspectivase desafios, cuja leitura recomendam "para pesquisadores de qualquer área do conhecimento" (DIAS; OLIVEIRA, 2019, p.11).

Dados e informação caminham de mãos dadas na Sociedade em Rede, ou Sociedade da Informação e do Conhecimento. (2019, p.11). Estejamos atentos para este campo que estabelece fronteiras com a interdisciplinaridade da Ciência da Informação.

0 futuro tornou-se presente mais rapidamente do que poderíamos pensar, e nos impele a prospectar, investigar, registrar e preservar os dados que logo se transformarão em informação a caminho do conhecimento. Ciência de Dados e Ciência da Informação, juntas, vivendo hoje de olho no amanhã.

Gustavo Henrique de Araújo Freire

Isa Maria Freire

Editores

\section{Referências}

DIAS, G. A.; OLIVEIRA, B. M. J. F. de. Dados científicos > perspectivas e desafios. João Pessoa: Ed. UFPB, 2019.

SEMELER, A. R.; PINTO, A. L. Os diferentes conceitos de dados de pesquisa na abordagem da biblioteconomia de dados. Ciência da Informação, v. 48, n. 1, 2019.

SARACEVIC, T. Integrating in librarianship information. Ciência da Informação, v. 8, n. 1, 1979.

WIKIPEDIA. Ciência de dados. Disponível em: https://pt.wikipedia.org/wiki/Ci\%C3\%AAncia_de_ dados. Acesso 24 ago 2019. 